\title{
Analytic Study of 594 Type 2 Diabetic Patients Attending a Private Diabetes and Endocrine Center at Dallah Hospital in Riyadh, KSA
}

\author{
Saher Safarini*, Hilali H Hilali, Samia Elsheikh and Abdalla K Omer
}

Diabetes and Endocrine Center, Dallah Hospital, KSA

\begin{abstract}
Objective: To assess the inadequate glycemic control and its correlates among type 2 diabetes patients attending a private diabetes and endocrine center at Dallah Hospital - Riyadh, (KSA) and to compare our results with other previous similar studies.

Material and method: An analytical study was carried out on a 594 patients with type 2 diabetes who were attending the diabetes and endocrine center at Dallah Hospital in Riyadh during the period from February to April 2011. Data were collected by the treating physicians themselves at the end of each patient visit and entered on a special standard form (Microsoft Excel) program.

Results: The mean average of $\mathrm{HbA} 1 \mathrm{c}$ in this study was $7.81 \% .35 \%$ of patients achieved adequate glycemic control of $\mathrm{HbA} 1 \mathrm{c}$ less than $7 \%$ (according to ADA recommendation). There is correlation between duration of diabetes, patient's age, dyslipideamia and the glycemic control, but this correlation does not exist with the gender of the patient or patient's body mass index for those who reached a good glycemic control.

Conclusion: Our analysis study conclude a positive correlation between the duration of diabetes, patients' age dyslipidemia and the glycemic control, which is not shown with body mass index or gender of the patients. More efforts on health education should be spent to convince patients on the importance of life style modification and compliance with the treatment to achieve a satisfactory targeted level of $\mathrm{HbA} 1 \mathrm{c}$.
\end{abstract}

Keywords: Glycemic control; HbAlc; Diabetes mellitus; Dallah hospital - Saudi Arabia

Objective: To determine the percentage of inadequate glycemic control and its correlates among type 2 diabetes patients attending a private diabetes and endocrine center at Dallah Hospital - Riyadh (KSA). And to compare our results with other previous similar studies which reported the unsatisfactory glycemic control in type 2 diabetes could be related not only to treatment modality and adherence to life style changes, but also to other factors like gender, duration of diabetes, body mass index, and dyslipidemia [1].

\section{Introduction}

Diabetes mellitus is the most prevalent non-communicable metabolic disorder, presenting a significant public health burden in all aspects [2]. WHO estimated the affected numbers with diabetes in the year 2000 to reach as much as 170 million, the figure may jump to 366 millions in year $2030[3,4]$. The disease considered to be more frequent in Arab Gulf states compared to Europe and North America [5]. Numbers of clinical studies conducted in Kingdom of Saudi Arabia, demonstrated the high prevalence of the disease almost (34.1\%) in Saudi males and (27.6\%) in females [6,7] which represent a major public health, in addition to the social and economic burden. Results from mega trails in the recent years had established the central role of tight and sustained glycemic control among type- 1 and type- 2 diabetic patients, as a result it has been proposed to manage and maintain HAlc to value less than 7\% [8]. DCCT and UKPDS clearly demonstrates the link between glycemic control and diabetes complications and UKPDS proved that, as much as $1 \%$ reduction in HbAlc led to $21 \%$ reduction of death related to diabetes, $14 \%$ in myocardial infarction and $37 \%$ in microvascular complications [9]. This results motivated health care providers and patients to achieve the recommended HbAlc goal $[10,11]$. Some previous studies have reported the unsatisfactory glycemic control in type 2 diabetes could be related not only to treatment modality and life style changes, but also to other factors like gender, duration of diabetes, body mass index, and dyslipidemia [1], but our study shows some different results.

\section{Material and Method}

This analytical study designed to estimate the percentage rates of uncontrolled diabetic patients and its correlates among adult population of type 2 diabetes receiving health care at a private diabetes and endocrine center, which is a part of Dallah hospital (350 beds capacity) and have 4 consultants endocrinologist, 2 senior registrar, 2 specialist, one dietitian and 3 health educators, the center receives Saudi and non Saudi patients from all over Riyadh city. $85 \%$ of our patients have medical insurance while $15 \%$ are self paying patients. The policy at the center recommend that each diabetic patient should receive complete diet counseling and health education settings by a certified clinical nutritionist and health care educator along with foot care counseling when applicable, and a routine laboratory tests following a fixed protocol used in the center according to the ADA recommendations [10] including HbA1c, Lipid profile, kidney function tests and microalbuminuria.

*Corresponding author: Saher Safarini, Diabetes and Endocrine Center- Dallah Hospital, P.O. Box 87833 Riyadh, 11652, Riyadh - Kingdom of Saudi Arabia, E-mail sahersafarini@yahoo.com

Received September 06, 2012; Accepted November 26, 2012; Published November 30, 2012

Citation: Safarini S, Hilali HH, Elsheikh S, Omer AK (2012) Analytic Study of 594 Type 2 Diabetic Patients Attending a Private Diabetes and Endocrine Center at Dallah Hospital in Riyadh, KSA. J Diabetes Metab 3: 234. doi:10.4172/21556156.1000234

Copyright: $\odot 2012$ Safarini S, et al. This is an open-access article distributed under the terms of the Creative Commons Attribution License, which permits unrestricted use, distribution, and reproduction in any medium, provided the original author and source are credited. 
A special standard data collection (Microsoft Excel) program used in the study which contain, information about patients gender, age, nationality, type and duration of diabetes, level of patient education, type of anti diabetic medication and doses (including Insulin, Metformin, Sulfonylurea, Acarbose, Thiazolidinediones and DPP-4 inhibitors) as well as compliance to medications, the blood pressure measurement (taken 5 min after rest in setting position with a Riester brand sphygmomanometer), Body mass index was calculated by dividing the body weight (in kilograms) by the height (in meters) squared $\left(\mathrm{BMI}=\right.$ weight $/$ height $\left.^{2}\right)$, data about smoking habits, patients adherence to diet, exercise, and self blood glucose monitoring at home were noted. Other associated diseases and co-morbidities as well as diabetes complications like erectile dysfunction in men, peripheral neuropathy in both sex, detection of background diabetic retinopathy were assessed by using a non mydriatic retinal camera (TRC-NW300); history of coronary heart diseases and cerebrovascular accident disease were documented as well, after revision of cardiologist or neurologist notes in patients files, by the clinical findings or by brain scan imaging in case of cerebrovascular accident.

Also all medications prescribed to patients for hypertension, hyperlipidemia and the use of Aspirin (primary or secondary prevention) were documented. The data entered in the excel sheet program by the treating physicians themselves at the end of each patient visit.

A total of 594 patients of age more than 18 years who had type2 diabetes were drawn for the study, in the diabetes and endocrine center at Dallah Hospital in Riyadh- Kingdom Saudi Arabia, during the period of February to April 2011. The patients' inclusion criteria include those who have been followed up in the center for at least one year or more, with regular follow up visits (at least 4 visits/year) and who had complete data information in their hospital file. Patients excluded from study include patient with type-1 diabetes, patient under age of 18 year or type $-2 \mathrm{DM}$ with incomplete data in their file or those who have less than 3 visits/year, pregnant ladies with diabetes or gestational diabetes and patients on hemodialysis were excluded in addition to patients with anemia to avoid any factors that may have negative impact in $\mathrm{HbAlc}$ value.

Techniques used for testing HhAlc and microalbuminuria are the latex immunoagglutination inhibition assay (DCA systems) [12], and the dry chemistry technique (Vitros) were utilized for lipids testing, study was approved by the hospital ethical committee.

\section{Results}

The demographic characteristics in 594 patients showed the different level of education, where $39.2 \%$ of patients have got college or university degree, $25 \%$ completed secondary schools while $9.5 \%$ stopped their education at elementary schools and $26.3 \%$ were without formal education. More over the sample showed that $74 \%$ of the patients were Saudi and 26.3\% were non Saudi, out of them 283 (48\%) females and $310(52 \%)$ were male with mean age of both sex of 55.5 years. $7 \%$ of the patients were under 40 -years of age while more than one third of the studied sample were above 60 -years. The mean duration of diabetes in both sex was about 10.6 years with mean body mass index (BMI) of 32.0 (Table 1).

The mean average of HbAlc in this study was $7.81 \%$ (Table 2), and patients reach adequate glycemic control of less than $7 \% \mathrm{Hbalc}$ were (35\%) 208 of the patients, while patients with fair control HbAlc between $7.1-8 \%$ were (30.5\%) 181 of the patients. The remaining 205 (34.5\%) patients had inadequate glycemic control with $\mathrm{HbA} 1 \mathrm{c}$ of more than $8 \%$. The average HbAlc in females and males was found almost same as $7.84 \%$ and $7.78 \%$ respectively. The majority of patients 518 (87\%) taking one to three drugs for diabetes, $5.6 \%$ taking 4 drugs or more and only $6.7 \%$ of the patients were controlled on diet alone. The percentage of patients taking insulin alone or with OHAs constitutes $27 \%$ of the patients. Surprisingly $40.7 \%$ of our patients were taking DPP-4 inhibitors which are a new class of OHAs introduced recently to gulf markets.

Patients on Aspirin as primary or secondary prevention were almost $57.2 \%$ of the patients (Table 2 ) and $436(73.4 \%)$ of the patients from the studied sample were taking treatment for hyperlipidemia (statins or fibrates) out of them $333(74 \%)$ patients reached LDL-C level of $<2.6 \mathrm{mmol} / \mathrm{l}$ and only $296(66 \%)$ reached target of less than 1.7 $\mathrm{mmol} / \mathrm{l}$ for triglycerides. More over $71 \%$ of male patients have HDL more than $1 \mathrm{mmol} / \mathrm{l}$, compared to $56 \%$ of females with HDL-c of more than $1.2 \mathrm{mmol} / \mathrm{l}$.

Numbers of patients taking antihypertensive treatment were almost 336 (57\%) out of them 284 (84.4\%) patients got their systolic blood pressure $<130(\mathrm{mmHg})$ while $305(90.8 \%)$ patients got diastolic blood pressure $<80(\mathrm{mmHg})$. Urine protein examination revealed that $25 \%$ of the patients demonstrated microalbuminuria (less than 300 $\mathrm{mg}$ ) while $5 \%$ have frank proteinuria of more than $300 \mathrm{mg}$ (Table 3).

The study also showed that $18 \%$ of the male patients are regular smokers, $40.4 \%$ of patients perform regular physical activities of more than 30 minutes a day. $57.7 \%$ of the patients were adhering to diet plan as recommended by the dietitian, while $84.2 \%$ of patients performing the self blood glucose monitoring at home of more than 2 times/week,

\begin{tabular}{|c|c|c|}
\hline & No. of patients & $\%$ \\
\hline \multicolumn{3}{|l|}{ Level of education } \\
\hline College or university level & 232 & $39.2 \%$ \\
\hline Secondary school level & 150 & $25 \%$ \\
\hline Elementary school level & 56 & $9.5 \%$ \\
\hline No formal education & 156 & $26.3 \%$ \\
\hline \multicolumn{3}{|l|}{ Nationality } \\
\hline Saudi & 437 & $74 \%$ \\
\hline Non-Saudi & 157 & $26 \%$ \\
\hline \multicolumn{3}{|l|}{ Sex } \\
\hline Male & 310 & $52 \%$ \\
\hline Female & 284 & $48 \%$ \\
\hline \multicolumn{3}{|l|}{ Age (year ) mean 55.6} \\
\hline$<40$ & 49 & $7 \%$ \\
\hline $40-59$ & 347 & $59 \%$ \\
\hline $60-69$ & 127 & $22 \%$ \\
\hline$>70$ & 70 & $12 \%$ \\
\hline \multicolumn{3}{|c|}{ Duration of DM 2 (years) mean 10.6} \\
\hline$<5$ & 156 & $26 \%$ \\
\hline $5-10$ & 143 & $24 \%$ \\
\hline $10-15$ & 126 & $21 \%$ \\
\hline$>15$ & 169 & $28 \%$ \\
\hline \multicolumn{3}{|l|}{ Body Mass Index $\left(\mathrm{kg} / \mathrm{m}^{2}\right)($ mean 32$)$} \\
\hline$<19.9$ under weight & 2 & $0.3 \%$ \\
\hline 20-25 normal weight & 68 & $11 \%$ \\
\hline 25.1-30 over weight & 181 & $31 \%$ \\
\hline$>30.1 \quad$ obese & 343 & $58 \%$ \\
\hline
\end{tabular}

Table 1: Demographic characteristics of type 2 diabetic patients $(n=594)$. 
Citation: Safarini S, Hilali HH, Elsheikh S, Omer AK (2012) Analytic Study of 594 Type 2 Diabetic Patients Attending a Private Diabetes and Endocrine Center at Dallah Hospital in Riyadh, KSA. J Diabetes Metab 3: 234. doi:10.4172/2155-6156.1000234

Page 3 of 5

and $93 \%$ of the studied sample were adherent to their treatment (Table $4)$.

Concerning the complication and associated pathology of type 2 diabetes, the adverse effect of hyperglycemia and metabolic disorder leading to serious complications were documented in the study as follow, $24.5 \%$ of male patients have got erectile dysfunction, $23 \%$ have painful peripheral neuropathy needed treatment, $16.2 \%$ have retinopathy,
$12.5 \%$ have ischemic heart disease, $3.3 \%$ have cerebrovascular accident $3.2 \%$ got diabetic foot, and 30\% have documented microalbuminuria or proteinuria and $14.5 \%$ have primary hypothyroidism as associated disorder (Table 5).

\section{Discussion}

This analytical study was conducted to estimate the percentage

\begin{tabular}{|c|c|c|}
\hline & No. of patients & $\%$ \\
\hline $\begin{array}{l}\text { Hb A1c (mean } 7.81 \% \text { ) } \\
<7 \% \\
7.1-8 \% \\
8.1-9 \% \\
\text { More than } 9 \%\end{array}$ & $\begin{array}{l}208 \\
181 \\
97 \\
108\end{array}$ & $\begin{array}{l}35.0 \% \\
30.5 \% \\
16.3 \% \\
18.2 \%\end{array}$ \\
\hline $\begin{array}{l}\text { Hb A1c (mean according to sex) } \\
\text { Average } \mathrm{Hb} A 1 \mathrm{c} \text { (in females) } \\
\text { Average } \mathrm{Hb} \text { A1c (In males) }\end{array}$ & $\begin{array}{l}284 \\
310\end{array}$ & $\begin{array}{l}7.84 \% \\
7.78 \%\end{array}$ \\
\hline $\begin{array}{l}\text { Number of anti diabetic drugs pre } \\
\text { Diet only } \\
\text { One drug } \\
2 \text { drugs } \\
3 \text { drugs } \\
4 \text { drugs } \\
5 \text { drugs }\end{array}$ & $\begin{array}{l}40 \\
151 \\
204 \\
163 \\
33 \\
3\end{array}$ & $\begin{array}{l}6.7 \% \\
25.4 \% \\
34.3 \% \\
27.4 \% \\
5.6 \% \\
0.5 \%\end{array}$ \\
\hline \multicolumn{3}{|c|}{ Type of anti diabetic drugs prescribed } \\
\hline Insulin only & 30 & $5.0 \%$ \\
\hline Insulin \& OHAs & 133 & $22.0 \%$ \\
\hline Metformin & 510 & $85.9 \%$ \\
\hline DPP 4 & 242 & $40.7 \%$ \\
\hline Sulfonylureas & 338 & $56.9 \%$ \\
\hline TZDs & 97 & $16.3 \%$ \\
\hline Acarbose & 8 & $1.3 \%$ \\
\hline \multicolumn{3}{|c|}{ Medications for Hyperlipidemia, HTN and the use of Aspirin } \\
\hline Aspirin & 340 & $57.2 \%$ \\
\hline ARBs & 222 & $37.4 \%$ \\
\hline ACE & 79 & $13.3 \%$ \\
\hline Statins and or fibrates & 436 & $73.4 \%$ \\
\hline
\end{tabular}

Table 2: HbA1c level and Anti-diabetic medications used for treatment of DM type 2 (patients $n=594$ ).

\begin{tabular}{|c|c|c|c|}
\hline & & No of patients & $\%$ \\
\hline 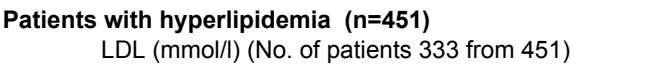 & $<2.6$ & 333 & $74 \%$ \\
\hline TG (mmol/l) (No. of patients 296 from 451) & $<1.7$ & 296 & $66 \%$ \\
\hline $\begin{array}{l}\mathrm{HDL}(\mathrm{mmol} / \mathrm{l}) \text { Male (No. of patients } 163 \text { from 230) } \\
8 \text { patients have missed data }\end{array}$ & $\geq 1.0$ & 171 & $71 \%$ \\
\hline $\begin{array}{l}\text { Female (No. of patients } 120 \text { from } 213 \text { ) } \\
9 \text { patients have missed data }\end{array}$ & $\geq 1.2$ & 120 & $56 \%$ \\
\hline $\begin{array}{l}\text { Urine protein examination }(\mathrm{mcg} / \mathrm{mg} \text { creatinine). patients }(\mathrm{r} \\
\text { Normal } \\
\text { Microalbuminuria } \\
\text { Proteinuria }\end{array}$ & $\begin{array}{l}<30 \\
31-299 \\
>300\end{array}$ & $\begin{array}{l}387 \\
135 \\
25\end{array}$ & $\begin{array}{l}71 \% \\
25 \% \\
5 \%\end{array}$ \\
\hline $\begin{array}{l}\text { Patient taking anti hypertensive treatment }(\mathrm{n}=336) \\
\text { Systolic blood pressure }(\mathrm{mmHg}) \\
\text { Diastolic blood pressure }(\mathrm{mmHg})\end{array}$ & $\begin{array}{l}<130 \\
<80\end{array}$ & $\begin{array}{l}284 \\
305\end{array}$ & $\begin{array}{l}84.40 \% \\
90.80 \%\end{array}$ \\
\hline
\end{tabular}

HDL-C: High Density Lipoprotein-Cholesterol; LDL-C: Low Density Lipoprotein-Cholesterol; TG: Triglycerides

Table 3: Results of lipids profile, protein in urine and BP measurements (patients $n=594$ ). 
rates of controlled and uncontrolled diabetic patients and its correlates among type 2 diabetes population receiving satisfactory health care according to international standard at a private diabetes and endocrine center.

In this study, $35 \%$ of the patients got an adequate glycemic control of $\mathrm{HbA} 1 \mathrm{c}$ less than $7 \%$ (according to ADA recommendation)

\begin{tabular}{|l|l|l|}
\hline & No. of patients & $\%$ \\
\hline Smoker(males) & 56 & $18.0 \%$ \\
\hline $\begin{array}{l}\text { Physical Activities (Participate in at least 30 min / } \\
\text { day of physical exercise) }\end{array}$ & 240 & $40.4 \%$ \\
\hline $\begin{array}{l}\text { Adherence to Diet (Following eating plan as } \\
\text { recommended by dietitians) }\end{array}$ & 343 & $57.7 \%$ \\
\hline Adherence to Treatment & 550 & $93.0 \%$ \\
\hline Self Monitoring Blood Glucose at home & 500 & $84.2 \%$ \\
\hline
\end{tabular}

Table 4: Life style and measures of compliance (patients $n=594$ ).

\begin{tabular}{|l|l|l|}
\hline Micro proteinuria( 31-299) $\mathrm{mcg} / \mathrm{mg}$ creatinine & 135 & $25 \%$ \\
\hline Erectile dysfunction (males) & $76 / 310^{*}$ & $24.5 \%$ \\
\hline Peripheral neuro pathy & 137 & $23.0 \%$ \\
\hline Retinopathy & 96 & $16.2 \%$ \\
\hline Hypothyroidism & 86 & $14.5 \%$ \\
\hline Ischemic heart disease & 74 & $12.5 \%$ \\
\hline Proteinuria $>300 \mathrm{mcg} / \mathrm{mg}$ creatinine & 25 & $5.0 \%$ \\
\hline Cerebro-vascular accident & 20 & $3.3 \%$ \\
\hline Diabetic foot & 19 & $3.2 \%$ \\
\hline
\end{tabular}

*Total numbers of males

Table 5: Complication \& associated pathology of diabetes type 2 (Total no. of patients 594).

\begin{tabular}{|c|l|l|}
\hline Body Mass Index $\left(\mathbf{k g} / \mathbf{m}^{2}\right)($ mean $\mathbf{3 2})$ & No.of patients and \% & HbA1c mean\% \\
\hline $20-25$ normal weight & $68(11 \%)$ & $7.83 \%$ \\
\hline $25-30$ over weight & $181(31 \%)$ & $7.85 \%$ \\
\hline$>30$ obese & $343(58 \%)$ & $7.78 \%$ \\
\hline
\end{tabular}

Non significant as the number very small $\mathrm{p}$-value $=0.18$

Table 6: HbA1c level according to BMI (patients $n=594$ ).

\begin{tabular}{|l|l|l|}
\hline Gender & No & HbA1c Average \\
\hline Male patients & 310 & $7.78 \%$ \\
\hline Female patients & 284 & $7.84 \%$ \\
\hline
\end{tabular}

Table 7: HbA1c level according to gender (patients $n=594$ ).

\begin{tabular}{|c|l|l|}
\hline Duration of DM 2 (years) mean 10.6 & No of patients and \% & HbA1c mean\% \\
\hline$<5$ & $156(26 \%)$ & $7.31 \%$ \\
\hline $5-10$ & $143(24 \%)$ & $7.58 \%$ \\
\hline $10-15$ & $126(21 \%)$ & $8.22 \%$ \\
\hline$>15$ & $169(28 \%)$ & $8.15 \%$ \\
\hline
\end{tabular}

$p$ - value $=0.0001$

Table 8: HbA1c level according to duration of diabetes (patients $n=594$ ).

\begin{tabular}{|c|l|l|}
\hline Age (year) mean 55.6 & No. of patients and \% & HbA1c mean\% \\
\hline$<40$ & $49(7 \%)$ & $7.65 \%$ \\
\hline $40-59$ & $347(59 \%)$ & $7.91 \%$ \\
\hline $60-69$ & $127(22 \%)$ & $7.65 \%$ \\
\hline$>70$ & $70(12 \%)$ & $7.72 \%$ \\
\hline mean & 148.25 & 7.73 \\
\hline Standard Deviation & 136.54 & 0.123 \\
\hline
\end{tabular}

$p-$ value $=0.0001$

Table 9: HbA1c level according to age group (patients $n=594$ )

\begin{tabular}{|l|l|l|l|}
\hline LDL and TG level & No of patients & HbA1c average & P-value \\
\hline LDL less than $2.6 \mathrm{mmol} / \mathrm{l}$ & 424 & $7.92 \%$ & \\
\hline LDL more than $2.6 \mathrm{mmol} / \mathrm{l}$ & 170 & $7.52 \%$ & 0.005 \\
\hline TG less than $1.7 \mathrm{mmol} / \mathrm{l}$ & 338 & $7.90 \%$ & \\
\hline TG more than $1.7 \mathrm{mmol} / \mathrm{l}$ & 256 & $7.68 \%$ & 0.005 \\
\hline
\end{tabular}

Table 10: Relation between dyslipidemia and HbA1c (patients $n=594$ ).

and $30.5 \%$ had $\mathrm{HbAlc}$ between $7.1-8 \%$ which is not so far from the expected goal. These findings are better than similar studies, done in our region or outside the region [13-18]. The adequacy of glycemic control widely varies due to availability of medications, patient's income, type of diabetes, patient's education, culture and life style of populations surveyed, as well as methods used to collect data. For example the percentages of type 2 diabetes patients achieving the target of $\mathrm{HbAlc}$ less than $7 \%$ in some other centers were about $24 \%$ in UK [13], 31\% in UAE [14], 17.6\% in Kuwait [15], 25\% in Finland [16] , 29\% in Singapore [17], 27\% in Brazil [18], 29.7\% in Thailand [19], 32\% in Canada [20], 27.5\% in Jordan [1].

Certainly it is difficult to reach a desired glycemic control goal despite the availability of all facilities as new classes of drug in form of oral or injectable medication (GLP-1 DPP-4 inhibitors, insulin and insulin analogs) in addition to modern insulin devices. In our study (27\%) of type 2 diabetes patients received insulin, and $93 \%$ of our patients adhered to their prescribed medication. Yet $2 / 3$ of the patients did not reach the desired HbAlc target of less than $7 \%$, this may be partially due to lack of adherence to recommended life style intervention.

The study showed no relation between gender, BMI and reaching a good glycemic control, as the HbAlc was almost the same in both sex and in normal, overweight or in obese patients, ranging between 7.78\%-7.85\% (Tables 6 and 7) with insignificant p-value.

More over study showed that glycemic control was significantly correlated with the duration of diabetes, as when the duration of the diabetes is less than 5 years the HbAlc average is $7.31 \%$ and if the duration is more than 10 years the HbAlc average is $8.22 \%$ (Table 8) this may be due to progressive nature of Beta cells destruction in diabetic patient. A correlation was noticed for other variables like, patient's age and level of lipid profile. Young age group or patients who have lower LDL or Triglycerides has better glycemic control \% (Tables 9 and 10). These findings are not consistent with the findings of a number of studies which reported, that younger age groups patients were associated with poor glycemic control [21].

\section{Conclusion}

Our study conclude a positive correlation between duration of diabetes, age of patients, dyslipidemia and the glycemic control, but no correlation between gender or body mass index in order to reach a good glycemic control.

Despite the great efforts done by the health care providers to reach the desired glycemic control goal, it's difficult to achieve an HbAlc level of less than $7 \%$.

\section{Acknowledgment}

The authors wish to thank Mr. Salah Saadeh, Statiscian at Dallah Hospital for his support in analysis the data.

\section{References}

1. American Diabetes Association (2010) Standards of Medical Care in Diabetes-2010. Diabetes Care 33: S11-S61. 
Citation: Safarini S, Hilali HH, Elsheikh S, Omer AK (2012) Analytic Study of 594 Type 2 Diabetic Patients Attending a Private Diabetes and Endocrine Center at Dallah Hospital in Riyadh, KSA. J Diabetes Metab 3: 234. doi:10.4172/2155-6156.1000234

2. Narayan KM, Gregg EW, Fagot-Campagna A, Engelgau MM, Vinicor F (2000) Diabetes--a common, growing, serious, costly, and potentially preventable public health problem. Diabetes Res Clin Pract 50: S77-S84.

3. Wild S, Roglic G, Green A, Sicree R, King H (2004) Global prevalence of diabetes: estimates for the year 2000 and projections for 2030. Diabetes Care 27: 1047-1053

4. Yach D, Stuckler D, Brownell KD (2006) Epidemiologic and economic consequences of the global epidemics of obesity and diabetes. Nat Med 12: $62-66$

5. Alwan A (1997) Non communicable diseases: a major challenge to public health in the region. Eastern Mediterranean Health $\mathrm{J}$ 3: 6-16.

6. Matthew E, Sreedharan J, Muttappallymyalil J, Sharbathi SA (2011) Commen on: Prevalence of diabetes mellitus in a Saudi community. Ann Saudi Med 31: 19-23.

7. (1993) The effect of intensive treatment of diabetes on the development and progression of long-term complications in insulin-dependent diabetes mellitus. The Diabetes Control and Complications Trial Research Group. N Engl J Med 329: 977-986.

8. (1998) Intensive blood-glucose control with sulphonylureas or insulin compared with conventional treatment and risk of complications in patients with type 2 diabetes (UKPDS 33). UK Prospective Diabetes Study (UKPDS) Group. Lancet 352: 837-853.

9. American Association of Clinical Endocrinologists and American College of Endocrinology (2002) Consensus statement on guidelines for glycemic control. Endoc Pract 8: 5-11.

10. Ahmad Khan $\mathrm{H}$ (2007) Clinical significance of $\mathrm{HbA1c}$ as a marker of circulating lipids in male and female type 2 diabetic patients. Acta Diabetol 44: 193-200.

11. Siemens. DCA Systems, Hemoglobin A1c Reagent Kit. A quantitative Assay for hemohlobin $\mathrm{A} 1 \mathrm{c}$ in Blood.
12. Fox KM, Gerber Pharmd RA, Bolinder B, Chen J, Kumar S (2006) Prevalence of inadequate glycemic control among patients with type 2 diabetes in the United Kingdom general practice research database: A series of retrospective analyses of data from 1998 through 2002. Clin Ther 28: 388-395.

13. Juma Al-Kaabi, Fatma Al-Maskari, Hussein Saadi, Bachar Afandi, Hasratal Parkar, et al. (2008) Assessment of Dietary Practice Among Diabetic Patients in the United Arab Emirates. Rev Diabet Stud 5: 110-115.

14. Al-Sultan F, Al-Zanki N (2005) Clinical epidemiology of type 2 diabetes mellitus in Kuwait. Kuwait Medical Journal 37: 98-104.

15. Valle T, Koivisto VA, Reunanen A, Kangas T, Rissanen A (1999) Glycemic control in patients with diabetes in Finland. Diabetes Care 22: 575-579.

16. Sabanayagam C, Shankar A, Saw SM, Tai ES, Lim SC, et al. (2009) Prevalence of diabetes mellitus, glycemic control, and associated factors in a Malay population in Singapore. Asia Pac J Public Health 21: 385-398.

17. Mendes AB, Fittipaldi JA, Neves RC, Chacra AR, Moreira ED Jr (2010) Prevalence and correlates of inadequate glycaemic control: results from a nationwide survey in 6,671 adults with diabetes in Brazil. Acta Diabetol 47: 137-145.

18. Worawongprapa O (2008) Glycemic control in diabetes with metabolic syndrome in community hospital. J Med Assoc Thai 91: 641-647.

19. Harris SB, Kapor J, Lank CN, Willan AR, Houston T (2010) Clinical inertia in patients with T2DM requiring insulin in family practice. Can Fam Physician 56: e418-424.

20. Khattab M, Khader YS, Al-Khawaldeh A, Ajlouni K (2010) Factors associated with poor glycemic control among patients with type 2 diabetes. J Diabetes Complications 24: 84-89.

21. El-Kebbi IM, Cook CB, Ziemer DC, Miller CD, Gallina DL, et al. (2003) Association of younger age with poor glycemic control and obesity in urban african americans with type 2 diabetes. Arch Intern Med 163: 69-75. 